(Uniwersytet Łódzki,

e-mail: rafal.zarebski@uni.lodz.pl)

ORCID: 0000-0003-1918-2169

\title{
NAZWY CZARNOSKÓRYCH MIESZKAŃCÓW AFRYKI WE WSPÓLCZESNYCH PRZEKEADACH NOWEGO TESTAMENTU NA TLE PRZEMIAN KULTUROWYCH
}

Na podstawie lektury słowników współczesnej polszczyzny, wybranych opracowań naukowych z zakresu różnych dziedzin, publikacji popularnonaukowych, wypowiedzi zamieszczanych w mediach (głównie w prasie i w Internecie), a także pytań i watpliwości kierowanych do rozmaitych poradni językowych, można odnieść nieodparte wrażenie, że użytkownicy języka maja problem $z$ neutralnym sposobem nazywania osób rasy czarnej. ${ }^{1}$ Wyrazem toczącej się dyskusji na ten temat może być choćby publikacja na stronie Rady Języka Polskiego opinii Marka Łazińskiego [2020], w której zaleca się unikanie słowa Murzyn w przestrzeni publicznej ze względu na konotacje, którymi ono obrosło.

Pomijając jednostki o wyjątkowo ujemnym zabarwieniu emocjonalnym, np. asfalt, czarnuch, w tym wywodzaca się $z$ wierszyka dla dzieci Juliana Tuwima mało poważna zapelatywizowana nazwę bambo, widzimy, że inne funkcjonujące w polszczyźnie sposoby określania osób czarnoskórych - mimo że niegdyś neutralne (choć nie zawsze w jednakowym stopniu) - zyskały na przestrzeni ostatnich lat również pejoratywny wydźwięk. Dyskusja na temat poszukiwania najbardziej odpowiednich nominacji dla osób, których przodkowie pochodzą z czarnej Afryki, toczy się oczywiście nie tylko w Polsce i Europie, ale i poza nią (przede wszystkim w Stanach Zjednoczonych), a na jej przebieg i kierunek w znacznym stopniu wpływają kwestie związane $z$ poprawnościa polityczna [zob. Łaziński 2007; 2014]. ${ }^{2}$

Na zasygnalizowany powyżej problem warto spojrzeć w kontekście ustaleń historycznojęzykowych. Zjawisko związane $z$ brakiem jednoznacznej, syntetycznej, neutralnej pod względem aksjologicznym jednostki leksykalnej odnoszącej się współcześnie do osoby czarno- // ciemnoskórej

1 Istotnym kontekstem dla prowadzonych tu rozważań może być studium S. Koziary i R. Przybylskiej [2017], poświęcone analizie ekwiwalentów przekładowych dotyczacych jednostek gość i obcy w polskich tłumaczeniach przypowieści ewangelicznej.

2 Szerzej pisze o tym także m.in. G. Zarzycka [2006, 143-144] w monografii poświęconej prasowemu wizerunkowi cudzoziemców studiujących w Łodzi. 
ma bowiem źródła w przeszłości. Jak wykazała analiza ekwiwalentów tłumaczeniowych odnoszących się do czarnoskórych mieszkańców Afryki w średniopolskich przekładach Nowego Testamentu (NT), początkowo leksem Murzyn i jego derywaty były neutralne pod względem stylistycznym i wartościującym. O braku obciązeń stylistycznych świadczy choćby wymienne używanie przez tego samego tłumacza jednostek Murzyn // Etiopczyk, Etiopianin, królowa murzyńska // królowa etiopska. Z czasem jednak pod naporem uwarunkowań pozajęzykowych rzeczownik Murzyn wraz $z$ innymi jednostkami ze swojego gniazda słowotwórczego obrósł konotacjami negatywnymi. ${ }^{3}$

Wobec trudności, jakie współczesnemu użytkownikowi polszczyzny sprawia wskazanie najbardziej adekwatnego określenia osoby czarnoskórej, warto sprawdzić, jak z tym problemem radza sobie autorzy współczesnych przekładów biblijnych. W tym celu poddano obserwacji tłumaczenia powstałe w dość rozległej perspektywie czasowej - druga połowa XX wieku i poczatek XXI w. Na przestrzeni tego okresu doszło do znacznych przemian kulturowych, społecznych i geopolitycznych (dziś - inaczej niż to było w XVI w. - osoba czarnoskóra nie musi być przede wszystkim mieszkańcem Afryki), o czym nie można zapomnieć w kontekście czynionych tu rozważań. Niemniej jednak zdecydowano się objąć wspólną analizą przekłady $z$ tego dość długiego okresu, traktując je jako współczesne. Interpretacji danych korpusowych służy odwołanie się do ustaleń leksykograficznych (w analizie uwzględniono ważniejsze słowniki dokumentujące leksykę XX-wieczną) oraz spostrzeżeń językoznawców i niejęzykoznawców dotyczących interesujaccej nas problematyki. Stanowia one istotne tło prowadzonych rozważań.

Analizą filologiczna objęto jednostki wyekscerpowane z 16 polskich przekładów biblijnych, opartych na różnych podstawach (greckim oryginale, łacińskiej Wulgacie), zróżnicowanych nie tylko wyznaniowo (przekłady protestanckie, katolickie, ekumeniczne itd.), ale także w zakresie technik i strategii tłumaczenia. ${ }^{4}$

W Dziejach Apostolskich leksemy odnoszace się do postaci pochodzacych z Afryki, najprawdopodobniej, jak o tym przekonuja znawcy przedmiotu [zob. Bosak 1996, 123, 432, 659; Keener 2000, 255], czarnoskórych, wystapiły trzykrotnie w obrębie dwóch wersetów (Ia, Ib, IIa):

I.

A on poszedł. Właśnie wtedy przybył do Jerozolimy oddać pokłon Bogu (Ia) Etiop, dworski urzędnik (Ib) królowej etiopskiej, Kandake, zarzadzajacy całym jej skarb-

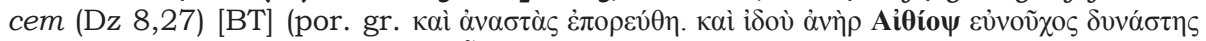

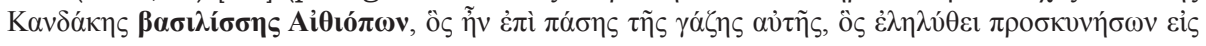

3 Na temat ekwiwalentów odnoszacych się do osób rasy czarnej w średniopolskich przekładach NT zob. Zarębski 2020.

${ }^{4}$ Informacje dotyczące przekładów wykorzystanych do badań znajdują się m.in. w BibP. 


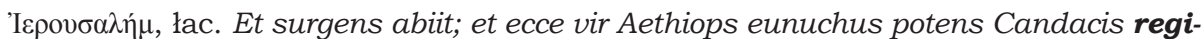
nae Aethiopum, qui erat super omnem gazam eius, qui venerat adorare in Ierusalem);

II.

W Antiochii, $w$ tamtejszym Kościele, byli prorokami i nauczycielami: Barnaba i Szymon zwany (IIa) Niger, Lucjusz Cyrenejczyk i Manaen, który wychowywat się razem z He-

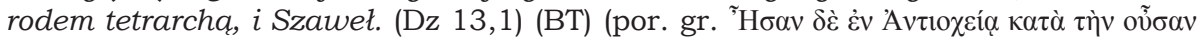

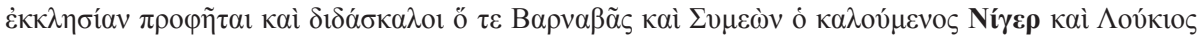

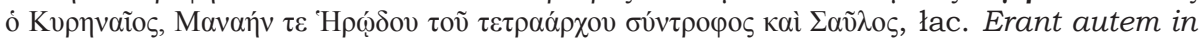
ecclesia, quae erat Antiochiae, prophetae et doctores: Barnabas et Simon, qui vocabatur Niger, et Lucius Cyrenensis, et Manaen, qui erat Herodis tetrarchae collectaneus, et Saulus) ${ }^{5}$.

Zestawienie wariantów w zakresie omawianych nazw w przekładach powstałych w XX i XXI w. przedstawia się następująco: ${ }^{6}$

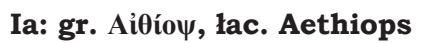

1. Etiop [BT, PK, PI, BWP],

2. Etiopczyk [BP, BPr, PE, PD, PBr, PNŚ, BPl, NTE, NTJ, NPrz],

3. Mą̇ Etiopii [PDb],

4. wysoki urzędnik [SŻ];

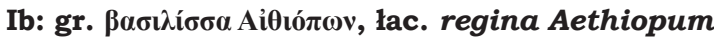

1. Królowa etiopska [BT, BP, PE, PK, PD, PDb, BPr, PNŚ, NTE, BWP], etiopska królowa [NPrz, SŻ], królowa [PBr],

2. Królowa Etiopii [BP1, NTJ],

3. Królowa Etiopów [PI];

IIa: gr. Níyep, lac. Niger

1. Szymon, zwany Niger [BT, PE, PDb, NTE, NTJ], Szymon zwany Nigrem [SŻ], Symeon, zwany Niger [BPr], Szymon z przydomkiem Niger [PK], Szymon (ten) nazywany Nigrem (PI), Symeon zwany Nigrem [PNŚ], Szymon zwany Nigerem [PBr], Szymon, posiadajacy również przydomek Niger [BWP], Symeon, noszacy przydomek Niger [NPrz], Szymon Niger [BP];

2. Szymon, zwany Murzynem [PD];

3. Szymon, zwany Czarnym [BPl].

Z przeglądu materiału współczesnego można wyciagnąć następujące wnioski. Tłumacze preferuja translokację jednostek obcych, wcześniej już przyswojonych do polszczyzny (Etiop(czyk), królowa etiopska, Niger), choć różnią się w zakresie wyboru formy słowotwórczej etnonimu. Zaskakuje pojawienie się niepodyktowanej tradycją tłumaczeniową bezsufiksalnej nazwy Etiop wobec powszechniejszej we współczesnej polszczyźnie formacji Etiopczyk [NSPP, SNW]. Jednostkowo zamiast etnonimu użyto wyrażenia wysoki urzędnik [SŻ], co prawdopodobnie jest wyrazem poszukiwania sposobu na uniknięcie kłopotliwej (?) nominacji. Podobnymi względami można zapewne tłumaczyć brak przydawki określającej po-

5 Tekst grecki i łaciński za: NA. Skróty tytułów ksiąg biblijnych za BT.

6 Pełne zestawienie wszystkich ekwiwalentów zob. Aneks. 
chodzenie królowej Kandaki w artystycznym przekładzie $\mathrm{PBr}$ - ekwiwalent królowa. $Z$ rzadka zamiast przymiotnika etiopska autorzy nowszych tłumaczeń sięgają po przydawkę rzeczowną wyrażoną dopełniaczem nazwy kraju bądź pluralnej nazwy mieszkańców. Ważne, że w stosunku do Etiopczyka czy Kandake nikt nie zastosował popularnych w dawnych przekładach form Murzyn, królowa murzyńska. Natomiast w odniesieniu do przydomka Szymona zaskakuje niemal zupełna rezygnacja z leksemu Czarny [wystapił tylko w jednym przekładzie - BPl], mającego silne oparcie w dawnej tradycji tłumaczeniowej i jednostkowe [PD] użycie rzeczownika Murzyn w ramach lokalizacji (Dz 13,1), w obrębie której nie zastosowały go nawet przekłady średniopolskie.

Warto się zastanowić, z czego wynika przedstawiony rozkład współczesnych wariantów translatorskich $\mathrm{w}$ odniesieniu do interesujacych nas nazw. Wydaje się, iż stan ten jest konsekwencja zjawisk zdecydowanie pozajęzykowych. Trzeba jednak podkreślić, że wpłynęły na to tylko w niewielkim stopniu te czynniki ekstralingwistyczne, które zazwyczaj determinują kształt stylistycznojęzykowy przekładów biblijnych, tj. podstawa tłumaczenia, metoda i technika przekładu oraz stosunek do tradycji tłumaczeniowej [zob. Bieńkowska 2002, 24-33]. O ile na przykład kształt językowy onimów (zwłaszcza bardziej popularnych, nazywających więcej niż jeden denotat) w polskich przekładach biblijnych jest zwykle determinowany w największym stopniu tradycja przekładowa, o tyle w naszym wypadku najistotniejsza funkcję pełni źródłowa postać nazwy. Wspomniano już, że przekłady współczesne w większości translokuja formy obce, jednocześnie adaptując je do systemu polszczyzny. Takie podejście do tekstu biblijnego wiąże się ściśle $z$ innym $z$ czynników wpływających na styl i język przekładu, a mianowicie ze strategia tłumaczeniowa. Ekscerpowane na potrzeby niniejszego opracowania translacje współczesne to przede wszystkim tłumaczenia filologiczne, dbajace o wierne odzwierciedlenie tekstu prymarnego, wobec czego zrozumiałe jest przejmowanie pewnych, zwłaszcza asemantycznych form obcych, do których w pewnej mierze należą omawiane etnonimy. Niewątpliwa zaletą tej praktyki jest możliwość uniknięcia $\mathrm{w}$ języku docelowym nazw w jakimś stopniu obciażonych stylistyczne. W ich obrębie właśnie mieszczą się jednostki Murzyn czy Czarny. Spróbujmy się zastanowić nad uwarunkowaniami, które wpłynęły na niechęć autorów do tradycyjnych nominacji. By to uczynić, odwołamy się do danych leksykograficznych.

Obserwacja hasła czarny już w SW dowodzi znacznego rozrostu polisemii tego przymiotnika w polszczyźnie doby nowopolskiej. Oprócz podstawowego znaczenia 'najciemniejszy kolor' wskazano tu liczne sensy, odnoszące się też do ludzkiego charakteru, postępowania, niższych warstw społecznych, wynikajace $z$ symboliki i negatywnych konotacji tej barwy, np. 'niski, podrzędny, pośledni', czarny gmin 'pospólstwo, motłoch', czarni chrześcijanie 'lud, chłopstwo, pospólstwo'; 'brzydki, szkaradny, zły, występny, podły, niski, nikczemny, zbrodniczy'; 'krytyczny, 
pesymistyczny' [SW]. SJPD dokumentuje spory przyrost kolokacji z jednostka czarny odnoszących się do negatywnych cech charakteru, postępowania człowieka, wykorzystywania go przez innych, ciężkiej pracy, np. czarny charakter, czarna owca, czarny robotnik 'robotnik wykonujacy ciężka pracę fizyczna, często licho płatną', czarni ludzie, czarni lud 'ogół robotników', w tym również do osób czarnoskórych, np. czarny kontynent, lad 'kontynent, ląd zamieszkały przez Murzynów, Afryka', czarny towar 'niewolnicy afrykańscy wystawieni na sprzedaż'. Po raz pierwszy też odnotowano tu rzeczownikowe użycia leksemu czarny w stosunku do osób rasy czarnej 'człowiek ciemnoskóry, ciemnowłosy; Murzyn'. Fakt ten zilustrowano kontekstem: „Trafiali się i na ziemiach polskich czarni, najczęściej jako jeńcy $z$ wojsk tureckich, których chętnie chowano jako dekoracyjną służbę" [Bystr.Dzieje I, 146], zaczerpniętym $z$ wydanych w 1932 r. Dziejów obyczajów w dawnej Polsce autorstwa Jana Bystronia [SJPD].

Słowniki najnowszej polszczyzny w zasadzie potwierdzają dane zawarte w SJPD, natomiast w odniesieniu do substantywizowanego przymiotnika czarny trzeba zauważyć, że na ogół odnotowują one znaczenie wskazujące na osobę czarnoskóra, ale ich autorzy nie sa jednomyślni w stylistycznej ocenie tej jednostki. Uznano ją zarówno za neutralna bez kwalifikatorów stylistyczno-pragmatycznych, por. Czarny 'mężczyzna rasy czarnej; Murzyn' [SWJP], czarny - Czarni ludzie należa do rasy o czarnej skórze: „Na festiwal przyjechali czarni jazzmani...”, „Czarna społeczność Ameryki domagała się swoich praw...”, „czarna dzielnica Nowego Jorku”, „Ludzie rasy czarnej”; używane jako rzeczownik - „Harlem to skupisko czarnych" [ISJP], jak i potoczna i pogardliwa, por. Czarny, Czarna w użyciu rzecz. pot. pogard. 'Murzyn, Murzynka' [USJP], Czarny II w użyciu rzecz. pot. pogard. 'człowiek rasy czarnej, Murzyn' [WSJPo1]. ${ }^{7}$ Leksem czarny w prymarnej funkcji przydawki przymiotnikowej jako człon grup nominalnych typu czarna społeczność, czarna kobieta, czarna ludność mających wspólny element znaczeniowy 'niewolnik; należący do rasy ludzi o najciemniejszym ze wszystkich kolorze skóry’ został odnotowany w WSJP.

Jeśli idzie o rzeczownik Murzyn, to jego funkcjonowanie w języku doby nowopolskiej i najnowszej prezentuje się następująco. W SJPD Murzyn (łac. Maurus, mieszkaniec północnej Afryki) 'człowiek należący do odmiany czarnej' to leksem nienacechowany emocjonalnie, choć przywołano tu również m.in. przenośne użycie jednostki ‘o tym, kto wykonywa za kogo jego pracę (...)', przysłowie „Murzyn zrobił swoje, murzyn może odejść” oraz frazeologizm biały murzyn 'o człowieku ciężko pracującym, wyzyskiwanym'. Jako potoczne określono użycie rzeczownika murzyn

7 Warto dodać, że niektóre słowniki współczesnej polszczyzny leksem czarny w użyciu rzeczownikowym odnosza tylko do 'księdza, zakonnika' [SPP], 'duchownego katolickiego' z kwalifikatorem pogard. [WSJP]. 
w sfrazeologizowanym porównaniu opalić się na murzyna 'opalić się na bardzo ciemny, brazowy kolor', przytoczono także leksem murzyn jako nieodnoszący się do człowieka: łow. 'młody cietrzew'. Leksykon zawiera również derywaty: Murzynka 'kobieta należąca do odmiany czarnej', $M u$ rzynek 'mały chłopiec Murzyn', Murzynię 'małe dziecko murzyńskie', Murzyniatko zdrob. od Murzynie, Murzyniak posp. 'chłopiec murzyński', Murzynisko ' $z$ pogarda, lekceważeniem lub serdecznościa o Murzynie', także w kontekstach apelatywnych, np. murzynek 'koń maści czarnej $z$ niewielka domieszka białej', pot. 'mocna, czarna kawa', murzynka 'odmiana truskawek' [SJPD]. ${ }^{8}$

Rozróżnienie na użycie leksemu Murzyn w funkcji etnonimu 'człowiek rasy czarnej' (pisany wielka litera) i potoczne 'człowiek wykonujacy odpłatnie pracę w imieniu kogoś bez ujawniania swego w niej udziału' (pisane małą litera) podtrzymuje SWJP, w którym również odnotowano frazemy biały murzyn; ciemno jak $w$ dupie u murzyna; na murzyna oraz derywaty Murzynka, murzynek 1. 'czarny placek kakaowy'; 2. reg. 'czarna kawa', murzyński itd.

Jako neutralne (nieopatrzone odpowiednimi kwalifikatorami) słowo Murzyn traktuja również inne słowniki współczesnej polszczyzny: 'człowiek należący do rasy czarnej’: „Murzyni amerykańscy sa potomkami Murzynów afrykańskich" [USJP], 'Murzyn to człowiek o bardzo ciemnej skórze, którego przodkowie wywodza sie z Afryki': „Z jeepa w biegu wyskoczyło trzech żołnierzy, Murzyn i dwaj biali”, „Na przekór stereotypowi handlarzem narkotyków okazał się biały adwokat, a dobrym policjantem Murzyn" [ISJP], 'człowiek rasy czarnej' [WSJPol]. Ich autorzy przytaczaja także podobne apelatywne, potoczne użycia interesującego nas rzeczownika: murzyn a) 'człowiek opalony na ciemny, brazowy kolor', b) 'ktoś, kto wykonuje pracę za kogoś, zwykle odpłatnie i bez ujawniania swego nazwiska', c) 'ktoś, kto ciężko pracuje, jest wykorzystywany i źle traktowany' oraz frazeologizmy: pot. wulg. Ciemno jak $w$ dupie u Murzyna, pot. fraz. biały murzyn, przysł. Murzyn zrobił swoje, murzyn może odejść [USJP; por. ISJP; WSJPol]. Od wyżej przytoczonych nie różni się $\mathrm{w}$ zasadzie zestaw derywatów $z$ gniazda słowotwórczego rzeczownika $\mathrm{mu}$ rzyn: Murzynka 'kobieta należąca do rasy czarnej', murzynka ogr. 'odmiana truskawek o drobnych ciemnoczerwonych owocach', b) owoc tej odmiany, Murzynek 'mały murzyński chłopiec', Murzyniątko pot. pieszcz.

8 Pewnym uzupełnieniem materiału XX-wiecznego moga być derywaty gniazda Murzyn odnotowane przez DLJP, por. Murzyneczka: „Kłamstwo, Murzyneczko, / Chodź, chodź, chodź. / Śpiewam o mej ziemi. / Chodź, chodź, chodź.” [A. Carpentier, Koncert barakowy, przeł. K. Wojciechowska, Warszawa, „Czytelnik" 1977, s. 54] [DLJP IV], murzyństwo: Dlaczego więc w tym względzie nie sa wydane zarządzenia, ażeby "białe murzyństwo" ograniczyć i dać możność przyjścia urzędnikom bez trudu na godzinę 8." [„Czasopismo Skarbowe”, Warszawa, sierpień 1936] [DLJP XXI]. 
'małe murzyńskie dziecko', pot. 'ciasto kakaowe', reg. krak. 'porcja mocnej czarnej kawy', murzyński, po murzyńsku, murzyńskość [USJP; ISJP].

Wydaje się, że jednostka Murzyn jest najbardziej rozpowszechnionym w polszczyźnie określeniem człowieka rasy czarnej. Obserwacja danych leksykograficznych oraz wypowiedzi funkcjonujacych w przestrzeni medialnej pozwala jednak dostrzec tendencję nie tylko do przesunięć semantycznych znamiennych dla tego leksemu (zwiazanych $z$ rozrostem jego polisemii i użyć apelatywnych), ale także stopniowej pejoratywizacji znaczenia. Mechanizm tych zmian można opisać następująco: wyraz prymarnie neutralny pod względem aksjologicznym na skutek uwarunkowań pozajęzykowych zostaje obarczony semem negatywnie wartościującym, który z czasem staje się dominujący [por. Puzynina 1992, 117-118]. Dość liczne frazemy z komponentem Murzyn // murzyn każdorazowo odsyłają do treści negatywnych, np. ktoś jest sto lat za Murzynami 'ktoś zacofany', biały murzyn 'osoba nadmiernie wykorzystywana przez innych', murzyn zrobił swoje, murzyn może odejść 'powiedzenie używane w sytuacji, kiedy ktoś stał się niepotrzebny, wobec czego go odprawiono', zdawać egzamin na murzyna 'wysłać kogoś na egzamin zamiast pójść samemu', ciemno jak $w$ dupie u murzyna 'bardzo ciemno'.

Istotna wydaje się uwaga zamieszczona w odniesieniu do rzeczownika murzyn 'człowiek należący do rasy czarnej' w WSJP, w której wyrażono explicite, że współcześnie wyraz ten jest uważany za obraźliwy. Tezę tę potwierdzają również przywołane w słowniku synonimy: asfalt, bambo, bambus, czarnuch, chociaż w opinii językoznawców ocena zabarwienia emotywnego tej nominacji nie jest jednoznaczna. Warto tu przywołać choćby fragment wypowiedzi Katarzyny Kłosińskiej, którą zamieszczono na stronie Poradni Językowej PWN w odpowiedzi na zapytanie z 31.01.2017 r. osoby zaniepokojonej pojawiajacymi się w reakcji na polityczna poprawność ograniczeniami dotyczacymi używania leksemu Murzyn:

Tymczasem w polszczyźnie o wiele gorsze konotacje niż Murzyn ma czarny, który jest dokładnym odpowiednikiem dość neutralnych w językach angielskim i francuskim Black, Noir. Można więc sądzić, że jednym z powodów postrzegania nazwy Murzyn jako obraźliwej jest to, że jej ekwiwalenty obcojęzyczne rzeczywiście są nacechowane negatywnie. Gdy czarnoskóre osoby, które przyjeżdżają do Polski np. na studia, szukaja w polsko-angielskim lub polsko-francuskim słowniku odpowiednika słowa Murzyn, znajdują obraźliwe nazwy Negro, Negre, co sprawia, że przypisują takie nacechowanie także polskiemu słowu.

Zgadzając się $z$ istnieniem negatywnych konotacji nazwy, uobecniających się przede wszystkim na płaszczyźnie frazeologicznej, autorka dodaje:

Konotacje te jednak nie sa, moim zdaniem, na tyle silne, by uważać, że nazwanie osoby czarnoskórej Murzynem jest obraźliwe (podobnie: wiele negatywnych skojarzeń budzi nazwa $\dot{Z} y d$, jednak używamy jej neutralnie, gdy odnosimy ją do osoby naro- 
dowości żydowskiej). (...) Przyznam, że dla mnie nazwa Murzyn nie ma w sobie nic obraźliwego, jeśli odnosi się do osoby czarnoskórej (...). Używają jej w stosunku do siebie niektórzy polscy obywatele mający ciemną skórę, także nie widząc w niej nic złego. Zdaję sobie jednak sprawę $z$ tego, że część czarnoskórych Polaków uważa ja za niestosowna, obraźliwą czy wręcz raniąca. Wiedząc o tym, staram się jej przy nich nie używać - nie w imię politycznej poprawności, lecz zwykłej ludzkiej życzliwości. ${ }^{9}$

Mimo przytoczonej opinii niejako w obronie neutralności stylistycznej wyrazu murzyn w przestrzeni publicznej i dyskursie medialnym pojawiaja się liczne głosy zachęcające do sięgania po poprawniejsze pod względem poprawności politycznej jednostki synonimiczne, np. Afrykańczyk, Afrykanin, imigrant z Afryki, mieszkaniec Afryki. Coraz częściej też słyszymy opinie, że najlepszym rozwiąaniem byłoby używanie za każdym razem nazwy konkretnej narodowości, np. Nigeryjczyk, Kameruńczyk itd. ${ }^{10}$ [zob. Zarzycka 2006, 347].

W przekładach NT wykorzystanych do badań nie wystąpiły inne nazwy człowieka rasy czarnej, które funkcjonują we współczesnej polszczyźnie: czarnoskóry książk. 'mający czarną skórę': „Czarnoskórzy mieszkańcy Afryki”, czarnoskóry, czarnoskóra w użyciu rzecz. książk. 'Murzyn, Murzynka' [USJP; por. ISJP; WSJP], ${ }^{11}$ czarnuch a) pot. 'mężczyzna o śniadej cerze lub czarnych włosach', b) pogard. 'o Murzynie', czarnucha pot. 'kobieta o śniadej cerze lub czarnych włosach' [USJP], czarnuch 'niektórzy mówią czarnuchy o Murzynach. Słowo potoczne i pogardliwe' [ISJP], czarnuch pogard. o Murzynie, czarnula o Murzynce [SPP]. Rzeczownik czarnuch z kwalifikatorem pot(oczny) notuje SJPD 'mężczyzna, chłopiec o ciemnej cerze lub czarnych włosach': „Pucybut nazywał się Henri; gadatliwy czarnuch bez nogi” [Brand.K.Troja 246]. Leksem ten bez wyraźnego odniesienia do osoby rasy czarnej 'rzecz czarna, człowiek czarny' został już zarejestrowany w SW. Nie opatrzono go ilustracja tekstowa, natomiast znalazła się tu jedynie informacja, że ma charakter gwarowy [Długosz-Kurczabowa 2015, 287-288]. Zbyt intensywne negatywne ob-

9 Kłopotliwy Murzyn [https://sjp.pwn.pl/poradnia/haslo/Klopotliwy-Murzyn;17473.html - dostęp 28.05.2018]. Zob. też „Murzyn, czarnoskóry, Afrykanin” [http:/ / filolozka.brood.pl/murzyn-czarnoskory-afrykanin/comment-page-2/ - dostęp 21.06.2018].

10 Zob. Afrykanin to nie Murzyn. Jak mówić by nie obrażać? [http://warszawa.wyborcza.pl/warszawa/1,87569,8000180,Afrykanin_to_nie_Murzyn_ Jak_mowic_by_nie_obrazac.html?disableRedirects=true - dostęp 28.05.2018]. Ciekawy głos w sprawie używania nazwy Murzyn i jej synonimów w dyskursie publicznym stanowi artykuł Dariusza Rosiaka pod znamiennym tytułem Czy murzyn to słowo obraźliwe?, zamieszczony w „Rzeczpospolitej” z 21.07.2012 [http:/ / www.rp.pl/artykul/914425-Czy-murzyn-to-slowo-obrazliwe-.html - dostęp 28.05.2018].

11 Por. czarnoskóry - osoba czarnoskóra ma czarny kolor skóry: „Ella Fitzgerald, czarnoskóra gwiazda swingu”. Używane jako rzeczownik: „Czterej czarnoskórzy, grożąc automatyczną bronią, natychmiast dokonali abordażu” [ISJP]. 
ciążenie sufiksu [zob. Grabias 1981; 1988] stanowi przeszkodę dla jego obecności w przekładzie biblijnym. W polszczyźnie XIX-wiecznej ang. wyraz nigger, który nie miał wówczas w języku źródłowym ujemnych konotacji, był oddawany za pomoca już wtedy obciążonego stylistycznie ekwiwalentu czarnuch. ${ }^{12}$

$\mathrm{Na}$ marginesie warto dodać, że przymiotnik czarnoskóry 'mający czarną skórę (Murzyn)' pojawił się dopiero w SJPD, mimo że w materiale XIX-wiecznym wystapiły composita $z$ członem czarny odnoszące się do ludzi, ${ }^{13}$ np. czarnosmutny 'sprawiający smutne wrażenie swoją czarnościa, żałobny', czarnoszyj, czarnotwarzy 'majacy twarz czarna, czarnowłosy itd. [SW]. Co ciekawe, w DLJP odnotowano synonimiczny względem przymiotnika czarnoskóry autorski neologizm czekoladowoskóry:

Najada chwyciła ją w objęcia. Przepełniona wzruszeniami, o które przyprawił ją czekoladowoskóry Ali, była skłonna do wylewu czułości, jak maciejka wieczorna do wydawania słodkich woni [J. Putrament „Wakacje”, Warszawa 1956, s. 239-240, „Czytelnik”] [DLJP IX].

Uwagę należy zwrócić na cytaty, którymi zilustrowano użycie złożenia czarnoskóry w SJPD, np. „Przodem czarnoskóre karlice niosły na głowach szeroko otwarte naczynia, z których rozwiewały się mocne, orzeźwiające wonie" [Święt.A.Duchy 213], z których - podobnie zreszta jak w wypadku większości innych kontekstów zamieszczonych w słownikach - wyłania się dość jednoznaczny wizerunek człowieka rasy czarnej jako niewolnika, służącego, kogoś prezentowanego zawsze w kontekście pracy fizycznej i życiowych niedogodności.

Istotnym tłem dla dyskusji wokół leksykalnych wykładników nazywających osobę czarnoskóra we współczesnej polszczyźnie sa badania Grażyny Zarzyckiej nad wizerunkiem cudzoziemców w prasie po 1989 r. $\mathrm{w}$ konfrontacji ze stereotypami etnicznymi. Autorka wynotowała następujące typy określeń: nominacje odwołujace się do kryterium narodowego i/lub państwowego, np. studenci z Etiopii, mieszkańcy Nigerii, Etiopczyk, Afrykanin, Afrykańczyk, nazwy uchodzace za neutralne, np. czarnoskóry, ale jednak obciążone ujemnym zabarwieniem emocjonalnym, np. Murzyn, czarny oraz zdecydowanie pejoratywne, np. dzikus, czarnuch, smoluch. Odwoławszy sie do definicji jednostki czarny zamieszczonej w Słowniku potocznej polszczyzny PWN J. Anusiewicza i J. Skawińskiego:

12 Z obciązenia stylistycznego przyrostka - uch możemy sądzić, że rzeczownik ten był nacechowany negatywnie pod względem emotywnym. Pejoratywny sufiks -uch ewokuje polszczyznę potoczna [Grabias 1988, 245].

13 Większość z tych złożeń opatrzono kwalifikatorem x - 'mało używany'. 
Określenie czarny, występujące jedynie w formie przymiotnikowej, choć zazwyczaj nie drażni osób rasy czarnoskórej, może być w wielu kontekstach komunikacyjnych odbieranej jako lekceważące

oraz do wypowiedzi J. Bralczyka, który wyraz Murzyn 'osoba o czarnym kolorze skóry' uznał za neutralny, badaczka przyjrzała się reakcjom studentów rasy czarnej na powyższe nazwy. Okazało się, że uważają oni określenie Murzyn i jego derywaty za dyskryminujace. ${ }^{14}$ Konstatując, że skoro

w języku polskim nie zostały wypracowane odpowiednie nazewnicze strategie językowe, które umożliwiłyby precyzyjne - i nie wzbudzające zastrzeżeń charakteryzowanych podmiotów - określanie osób czarnoskórych [Zarzycka 2006, 150],

badaczka postuluje, by w sytuacjach publicznych zaprzestać używania nazwy Murzyn ze względu na jej negatywne konotacje, a także innych określeń wartościujących, np. kolorowy (student) na rzecz jednostek o neutralnej lub pozytywnej konotacji uczuciowej, np. Afrykańczyk, Etiopczyk [zob. Zarzycka 2006, 143-145, 207, 212, 346; por. też Łaziński 2007; 2014; 2020].

Z obserwacji ekwiwalentów tłumaczeniowych $z$ pola nazw określajacych osobę czarnoskórą w polskich przekładach NT i analizy danych leksykograficznych można wyciągnąc następujące wnioski. Nominacja Murzyn pojawiła się w polszczyźnie wraz z pierwszymi tłumaczeniami biblijnymi. Pierwotnie rzeczownik ten oraz inne elementy $z$ jego gniazda słowotwórczego były neutralne pod względem stylistycznym i emocjonalnym, choć już w polszczyźnie XVI w. można dostrzec proces kształtowania się negatywnych konotacji [zob. Zarębski 2020]. Jak wynika $z$ badań Aleksandry Niewiary, w wizerunku Murzyna utrwalonym w dawnej literaturze pamiętnikarskiej podkreślano aspekt fizyczny, odnoszacy się do czarnego koloru skóry, oraz ekonomiczno-społeczny, wiążący się z niską pozycją tej ludności. Zdaniem badaczki stereotypizację Murzyna $z$ dominująca cechą niższości w drabinie społecznej widać już w pełni w XIX w. [zob. Niewiara 2000, 149-150]. Stereotyp ów znacznie się $z$ czasem pogłębił. Przekonuje o tym powiększający się zasób potocznych frazemów $z$ udziałem jednostek murzyn, murzynek, murzynka oraz użyć zapelatywizowanych. Odpowiedzią na tę swoistą deprecjację semantyki leksemów Murzyn, a także Czarny (w użyciu rzeczownikowym) w dzisiejszej praktyce translatorskiej jest wybór bezpieczniejszej strategii, polegającej

14 Autorka pisze, że słowo Negro użyte jako objaśnienie wyrazu Murzyn w Wielkim słowniku polsko-angielskim pod red. J. Stanisławskiego „czarnoskórym studentom jednoznacznie kojarzy się z okresem niewolnictwa; tak bowiem biali właściciele zwracali się do swoich czarnych niewolników. Używanie tego słowa w sytuacjach publicznych ze względu na negatywne konotacje jest zabronione w USA" [Zarzycka 2006, 143-144]. 
na przeniesieniu zaadaptowanej formy $z$ tekstu wyjściowego (Etiop, Etiopczyk, królowa etiopska, Niger). Natomiast tłumacz (np. PD, BPl), decydując się na użycie formy podyktowanej tradycją tłumaczeniową, może się narazić na zarzut posądzenia co najmniej o pewna anachroniczność językowa.

Ogólnie jednak można uznać, że współczesne strategie translatorskie dotyczące ekwiwalentów nazw z pola osoba czarnoskóra realizuja postulaty badaczy, którzy, dopełniając profil pojęcia 'człowiek rasy czarnej', konfrontują funkcjonujące w polszczyźnie nominacje $z$ ich postrzeganiem przez samych zainteresowanych, czyli osoby czarnoskóre. Ten napór warstwy pragmatycznej na kształt nominacji biblijnych nie jest niczym odosobnionym. Ma bowiem swoja paralelę w historii przekładowych ekwiwalentów z pola nazwy $\dot{Z} y d, z$ tym że tu stereotyp ukształtował się dużo wcześniej, jeszcze w staropolszczyźnie, wobec czego wcześniej, bo już od drugiej połowy XVI w., tłumacze zaczęli zastępować ją bardziej neutralnymi określeniami typu Judejczyk, mieszkaniec Judy [zob. Rzetelska-Feleszko 1998].

\section{Bibliografia i skróty}

Afrykanin to nie Murzyn. Jak mówić by nie obrażać?, http:/ / warszawa.wyborcza. pl/warszawa/1,87569,8000180,Afrykanin_to_nie_Murzyn_Jak_mowic by_nie_obrazac.html?disableRedirects=true [dostęp: 28.05.2018].

Kłopotliwy Murzyn, https://sjp.pwn.pl/poradnia/haslo/Klopotliwy-Murzyn;17473.html [dostęp: 28.05.2018].

Murzyn, czarnoskóry, Afrykanin, http:/ /filolozka.brood.pl/murzyn-czarnoskory-afrykanin/comment-page-2/ [dostęp: 21.06.2018].

BibP: Biblie polskie.pl. Przekłady Biblii na język polski, http:// bibliepolskie.pl/ przeklady.php [dostęp: 20.06.2018].

D. Bieńkowska, 2002, Polski styl biblijny, Łódź.

P.Cz. Bosak OP, 1996, Postacie Nowego Testamentu. Słownik - konkordancja, Poznań-Pelplin.

BP: Pismo Święte Starego i Nowego Testamentu w przekładzie z języków oryginalnych ze wstępami i komentarzami, oprac. zespół pod red. M. Petera i M. Wolniewicza, Poznań 1973-1975.

BPI: Pismo Święte Starego i Nowego Testamentu. Najnowszy przekład z języków oryginalnych z komentarzem, oprac. Zespół Biblistów Polskich, Częstochowa 2008; http://www.slowokrola.pl/\#/reading [dostęp: 19.06.2018].

BPr: Biblia to jest Pismo Święte Starego i Nowego Testamentu. Nowy przekład $z$ języków hebrajskiego i greckiego opracowany przez Komisje przekładu Pisma Świętego, Warszawa 1975; http:/ / biblia-online.pl/Biblia/ListaKsiag/ Warszawska [dostęp: 16.06.2018].

BWP: Pismo Święte Starego i Nowego Testamentu w przekładzie z języków oryginalnych, oprac. K. Romaniuk, Warszawa 1997; http://www.obohu.cz/ bible/index.php?k=Gn\&kap=1\&styl=PBWP [dostęp: 28.10 .2018 ]. 
DLJP IV: Depozytorium leksykalne języka polskiego. Nowe fotomateriały z lat 1901-2010, t. IV, oprac. A. Wawrzyńczyk, Warszawa 2010.

DLJP IX: Depozytorium leksykalne języka polskiego. Nowe fotomateriały z lat 1901-2010, t. IX, oprac. E. Małek, Warszawa 2011.

DLJP XXI: Depozytorium leksykalne języka polskiego. Fotoaddenda do Słownika warszawskiego, t. XXI, oprac. Piotr Wierzchoń, Warszawa 2014.

K. Długosz-Kurczabowa, 2015, Wyrazy, które intrygowały i które intryguja, Warszawa.

Ewangelie i Dzieje Apostolskie, Wstep. Nowy przekład z Wulgaty. Komentarz, oprac. E. Dąbrowski, Poznań-Warszawa-Lublin 1953.

S. Grabias, 1988, Stylistyczne wyznaczniki konstrukcji słowotwórczych, „Annales Universitatis Mariae Curie-Skłodowska”, Sectio FF. Philologiae, vol. VI, s. 233-247.

ISJP: M. Bańko (red.), 2000, Inny słownik języka polskiego PWN, A-Ó, Warszawa.

C.S. Keenner, 2002, Komentarz historyczno-kulturowy do Nowego Testamentu, red. nauk. wydania polskiego K. Bardski, W. Chrostowski, Warszawa.

S. Koziara, R. Przybylska, 2017, Gość czy obcy? Od przekazu ewangelicznego (Mt 25,31-46) do polskich przekładów biblijnych. Problemy ekwiwalencji, „LingVaria” XII, nr 2 (24), s. 73-91.

M. Łaziński, 2007, Murzyn zrobił swoje. Czy Murzyn może odejść? Historia i przyszłość słowa Murzyn w polszczyźnie, „Poradnik Językowy” z. 4, s. 47-56.

M. Łaziński, 2014, Jeszcze o słowie Murzyn i o stereotypach. Po lekturze artykułu Margaret Ohii Mechanizmy dyskryminacji rasowej w systemie języka polskiego, „Przegląd Humanistyczny” z. 5, s. 127-141.

M. Łaziński, 2020, Murzyn i Murzynka, https://rjp.pan.pl/index.php?option=com_ content\&view=article\&id=1892: murzyn-i-murzynka\&catid=44\&Itemid=208 [dostęp: 10.12.2020].

NA: Novum Testamentum Graece et Latine Textum Graecum post E. et E. Nestle communiter ediderunt B. et. K. Aland..., Stuttgart 1984, http://www.nestle-aland.com/en/read-na28-online/ [dostęp: 11.06.2018].

A. Niewiara, 2000, Wyobrażenia o narodach $w$ pamiętnikach $i$ dziennikach z XVI-XIX wieku, Katowice.

NPrz: Nowe Przymierze. Pismo Święte Nowego Testamentu, przekł. z j. grec. A. Hannig, P. Zaremba, Poznań-Bydgoszcz 2007; https://www.biblegateway.com/ [dostęp: 20.06.2018].

NSPP: A. Markowski (red.), 2000, Nowy słownik poprawnej polszczyzny PWN, Warszawa 2000.

NTE: Pismo Święte Nowego Testamentu. Przekład ekumeniczny z języków oryginalnych, wyd. IV poprawione, Warszawa 2007.

NTJ: Nowy Testament. Przekład na Wielki Jubileusz Roku 2000, z języka greckiego przełożył, wprowadzeniem i przypisami opatrzył ks. R. Popowski SDB, Warszawa 2002.

PBr: Święty Łukasz Ewangelista, Dzieje Apostolskie, przełożył z greckiego R. Brandstaetter, Warszawa 1984.

PD: Nowy Testament. Nowy przekład z języka greckiego na współczesny język polski, Warszawa 1991.

PDb: Pismo Święte Nowego Testamentu. Wstęp, nowy przekład z Wulgaty. Komentarz, oprac. E. Dąbrowski, wyd. VII, Poznań-Warszawa-Lublin 1958. 
PE: Pismo Święte Nowego Testamentu i Psalmy. Przekład ekumeniczny z języków oryginalnych, Warszawa 2001.

PI: Grecko-polski Nowy Testament. Wydanie interlinearne z kodami gramatycznymi, tłum. R. Popowski, M. Wojciechowski, Warszawa 1993.

PK: Pismo Święte Nowego Testamentu, tłum. S. Kowalski, Warszawa 1957.

PNŚ: Pismo Święte w przekładzie Nowego Świata, Nadarzyn 1997; https:// www.jw.org/pl/publikacje/biblia/bi12/ksi\%C4\%99gi-biblijne/ [dostęp: 18.06.2018].

J. Puzynina, 1992, Język wartości, Warszawa.

D. Rosiak, Czy murzyn to słowo obraźliwe?, „Rzeczpospolita” 21.07.2012, http:/ / www.rp.pl/artykul/914425-Czy-murzyn-to-slowo-obrazliwe-html [dostęp: 28.05.2018].

E. Rzetelska-Feleszko, 1998, Nazwy Żydów w słowiańskich przekładach Nowego Testamentu [w:] M. Kamińska, E. Umińska-Tytoń (red.), Funkcja słowa w ewangelizacji, Łódź, s. 213-224.

SJPD: W. Doroszewski (red.), 1958-1969, Słownik języka polskiego, Warszawa.

SNW: J. Grzenia, 2002, Słownik nazw własnych, Warszawa.

SPP: M. Czeszewski, 2006, Słownik polszczyzny potocznej, Warszawa.

SWJP: B. Dunaj (red.), 1996, Słownik współczesnego języka polskiego, Warszawa.

SŻ: Słowo Życia. Parafraza Nowego Testamentu we współczesnym języku polskim, Warszawa 1991, https://www.bible.com/pl/versions/137-psz-slowo-zycia [dostęp: 15.06.2018].

USJP: S. Dubisz (red. nauk.), 2003, Uniwersalny słownik języka polskiego, t. I, Warszawa.

WSJP: P. Żmigrodzki (red.), Wielki słownik języka polskiego PAN, http://www. wsjp.pl/do_druku.php?id_hasla=9750\&id_znaczenia=3682329 [dostęp: 28.05.2018].

WSJPol: E. Polański, E. Dereń (red.), 2008, Wielki słownik języka polskiego, Kraków.

R. Zarębski, 2020, Nazwy czarnoskórych mieszkańców Afryki w dawnych przekładach Nowego Testamentu, „Poradnik Językowy” z. 1, s. 79-91.

G. Zarzycka, 2006, Dyskurs prasowy o cudzoziemcach. Na podstawie tekstów o łódzkiej wieży Babel i osobach czarnoskórych, Łódź. 


\title{
Aneks
}

\begin{tabular}{|c|c|c|c|c|}
\hline \multirow[b]{2}{*}{$\begin{array}{l}\text { Prze- } \\
\text { kład }\end{array}$} & \multirow[b]{2}{*}{$\begin{array}{l}\text { Przynależność } \\
\text { konfesyjna }\end{array}$} & \multicolumn{3}{|c|}{ Lokalizacja } \\
\hline & & 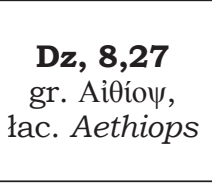 & $\begin{array}{c}\text { Dz 8,27 } \\
\text { gr. } \beta \alpha \sigma \imath \lambda i ́ \sigma \sigma \alpha \\
\text { Aîtó } \pi \omega v, \\
\text { łac. regina } \\
\text { Aethiopum }\end{array}$ &  \\
\hline $\mathbf{P D b}$ & katolicki & mąż Etiopii & królowa etiopska & Niger \\
\hline PK & katolicki & Etiop & królowa etiopska & Niger \\
\hline BT & katolicki & Etiop & królowa etiopska & Niger \\
\hline BP & katolicki & Etiopczyk & królowa etiopska & Niger \\
\hline BPr & protestancki & Etiopczyk & królowa etiopska & Niger \\
\hline PBr & katolicki & Etiopczyk & królowa & Niger \\
\hline PD & ekumeniczny & Etiopczyk & królowa etiopska & Murzyn \\
\hline $\mathbf{S} \dot{\mathbf{Z}}$ & protestancki & $\begin{array}{l}\text { wysoki } \\
\text { urzędnik }\end{array}$ & etiopska królowa & Niger \\
\hline PI & katolicki & Etiop & królowa Etiopów & Niger \\
\hline BWP & katolicki & Etiop & królowa etiopska & Niger \\
\hline PNŚ & $\begin{array}{c}\text { wyznanie świadków } \\
\text { Jehowy }\end{array}$ & Etiopczyk & królowa etiopska & Niger \\
\hline PE & ekumeniczny & Etiopczyk & królowa etiopska & Niger \\
\hline NTJ & katolicki & Etiopczyk & królowa Etiopii & Niger \\
\hline NPrz & ekumeniczny & Etiopczyk & etiopska królowa & Niger \\
\hline NTE & ekumeniczny & Etiopczyk & królowa etiopska & Niger \\
\hline BP1 & katolicki & Etiopczyk & królowa Etiopii & Czarny \\
\hline
\end{tabular}

\section{Names of black inhabitants of Africa in the contemporary translations of the New Testament against cultural transformations}

\author{
Summary
}

The contemporary translation strategies concerning equivalents of names from the field <a black person> in translations of the New Testament actualise the conclusions drawn by researchers, who confront the nominations that are in use in the Polish language with their perceptions by those in question, that is black people. A response to a certain depreciation of the semantics of the lexemes Murzyn, Czarny (when used as nouns) is the selection of a safer strategy, which consists in transferring the adapted form from the source text (Etiop, Etiopczyk, Królowa etiopska, Niger).

Keywords: translation studies - pragmalinguistics - translations of the New Testament - field of names < a black person> 